\section{California's nuclear war}

Californians will shortly give their view on nuclear power. Colin Norman reports on a critical referendum

When California voters work their way through their cluttered ballot papers in the June 8 primary election, they will decide more than the political fate of a handful of Presidential aspirants. They will also determine the future for nuclear power in California and, perhaps, in a number of other states as well.

A proposition, placed on the ballot by petition last year, would set such stringent controls on the construction and operation of nuclear power plants in California that, if passed, it could bring the nuclear industry to a grinding halt there. The outcome of the vote, the first ever plebiscite on nuclear power, is considered so important to the nuclear industry that, together with various supporting groups, it is pouring millions of dollars into a massive campaign to defeat the proposition. California's nuclear war, in fact, is even overshadowing the crucial battle between would-be Presidents for the state's delegates.

The vote will have repercussions extending well beyond California's borders, which is one reason why the matter has assumed such importance. For one thing, voters in several other states will be faced with the same choice in the November Presidential election. Similar propositions have already qualified for the ballots in Oregon and Colorado, they are also considered likely to qualify in North Dakota, Wyoming and Washington, and anti-nuclear groups are hoping to force nuclear referenda to be held in a number of other states next year. The theory is that a victory in California would give a huge boost to the antinuclear movement in those states. But, equally important, if the California proposition passes, it could undermine nolitical support for nuclear power in Washington and in state legislatures around the country.

In fact, the proposition's supporters can already claim a victory of sorts. Three bills, considered milder versions of the proposition, are sweeping. through the California legislature and are expected to be approved before the primary election. The bills were undoubtedly snawned by the huge publicitv given to the campaign, and they would probably never have stood a chance if the proposition had not gathered so much momentum.
Even at this late stage, the outcome of next Tuesday's vote is in some doubt. Although public opinion polls have consistently given opponents of the proposition the edge, the latest poll, conducted in mid-May, indicated that $29 \%$ of the voters were still undecided. Of the others, the poll found $30 \%$ in favour, and $51 \%$ opposed. Those figures are one reason why both sides are conducting a fierce campaign in the final days before the June 8 showdown.

The proposition, and the campaign which is now swirling noisily around it, is an interesting exercise in participatory democracy, and an object lesson in the wild ways of California politics. It will be Number 15 on the ballot papers, buried among questions on issues ranging from bank taxes to legalised bingo.

Formally known as the California Nuclear Safeguards Initiative, Proposition 15 would set the following conditions on the construction and operation of nuclear power plants in California:

- In the event of a nuclear accident, there must be no limit to the total damages which could be claimed by victims. At present, a federal law, the Price-Anderson Act, limits the liability of the nuclear industry to a total of $\$ 560$ million per accident.

- Within five years of passage of the proposition, the state legislature must have determined, by a two-thirds vote, that nuclear reactor safety systems will function correctly. Such a determination would be made on the basis of tests of the systems conducted "in actual operation".

- Similarly, the state legislature must have determined, by a two-thirds vote, that radioactive wastes can be stored without adversely affecting the health of Californians of their environment.

Unless those conditions are met, no new plants could be licenced and existing plants would be able to operate initially at only $60 \%$ of their rated capacity. Their output would then have to be decreased by $10 \%$ a year until thev are phased out in the mid-1980s.

The proposition qualified for the ballot early last year when its supporters gathered together the necessary 312,000 signatures. The early snonsors of the proposition were a San Francisco-based grouv called Californians for Nuclear Safeguards and a Los Angeles organisation known as Peoples' Lobby, but much of the original impetus came from Ralph Nader's organisation. An important addition to the pro-initiative forces was the Creative Initiative Foundation, a religious-philosophical group whose lobbying arm, known as Project Survival, joined the quest for signatures to qualify the proposition early in 1975 . Three nuclear engineers who quit their jobs at the General Electric Corporation last January to campaign for the proposition were all members of the Creative Initiative Foundation.

Opposition to the proposition is spearheaded chiefly by a committee of representatives from the nuclear industry, businessmen and labour leaders, called the California Council for Environmental and Economic Balance. Headed by Edmund G. Brown $\mathrm{Sr}$, former Governor of California and father of the present incumbent, the committee is well-financed and has hired a firm of campaign consultants to manage its effort.

Because there has been some confusion among Californians stemming from the fact that a 'no' vote on the proposition means a 'yes' for nuclear power, the committees recently changed their names. Supporters of the proposition now campaign under the banner of the "Yes on 15 Committee", while their opponents are headed by the "No on 15 Committee".

The rules, and perhaps the outcome, of the campaign were abruptly changed last January in favour of the opponents of Proposition 15. In the 1974 elections, California voters approved a proposition, again placed on the ballot by the Peoples' Lobby, which would set strict limits on the amounts of money spent by candidates in state-wide elections. But in January, the California Supreme Court ruled that the limits do not apply to campaigns for referenda, and money then began pouring into the coffers of the opposition groups, much of it coming from out-of-state utility and energy companies. By the time the vote is taken the various No on 15 groups will have spent about $\$ 7$ million, according to some estimates. By contrast, supporters of the proposition will have amassed only about $\$ 800.000$. Jovce. Koupal, who with her late husband Ed Koupal formed the basis for People's Lobby, claimed last week that the opponents are "buying the election".

In the last week or so of the campaign, the No on 15 Committee will sponsor a barrage of television and radio commercials, pushing the argument that the elimination of nuclear nower in California will cause unemplovment to rise and living standards to fall. And the $Y$ es on 15 Committee will have Ralph Nader stumping the state, arguing that energy can be conserved and alternative sources tapped, in such a manner that living standards 
will not suffer. Nobel laureates have already been ranged on both sides of the issue, and arguments have been traded back and forth about nuclear safety, safeguards and so on. The California campaign, in short, closely reflects the debate about the merits and hazards of nuclear power which has been raging nationally for the past few years.

But there is one additional issue in the campaign - the problem of operating nuclear reactors in a state where the seaboard is criss-crossed by geological faults, and the interior is almost devoid of cooling water. Because of those factors, experience with nuclear power in California has so far been vexing for the nuclear industry.

There are now three plants in operation, four under contruction, and some 20 more at various stages of planning. of the operating reactors, one small unit located north of San Francisco is now being reviewed by the Nuclear active fault has ben discovered close by, while another has been plagued with nagging technical problems ever since Regulatory Commission because an

it began operating early last year. A storm of controversy has recently arisen over two reactors under construction in Diablo Canyon, midway between San Francicso and Los Angeles, because an offshore fault has been discovered some 3 miles from the site. And it can safely be assumed that similar site problems will arise for future reactors.

Supporters of Proposition 15 thus have a plump target to shoot at, but the opponents are also not short of big guns. One of their chief arguments is that California already imports some $22 \%$ of its energy from the other states, and that without nuclear power its dependence on other regions will increase greatly. A substantial source of imported energy at present is a series of dams on the Colorado River, and a number of coal-fired power stations in Utah. But the Colorado is already dammed so heavily that it no longer reaches the sea (it disappears into the sand in Mexico), and Utah residents are growing reluctant to put up with air pollution in order to supply Los Angeles with power. A few weeks ago,

\section{Earthquake money}

A large helping of money for seismology, together with the establishment of a top-priority programme to reduce the destructiveness of future earthquakes, is promised in a bill approved without debate last week by the US Senate. Proposed by Senator Alan Cranston, the senior Senator from California, the bill has been hovering in the congressional wings for nearly four years; it was rushed to centre stage and swiftly passed last month in the wake of the destructive earthquakes in Italy and the Soviet Union.

If it survives the rest of the congressional process intact, the bill would authorise expenditures of some $\$ 150$ million over the next three years on a massive programme of research on earthquake prediction, efforts to improve the resistance of buildings to major shocks, studies of the social and psychological consequences of earthquakes, and how to issue earthquake warnings without adding to the disaster.

The bill would also establish a toplevel committee of 15 people, appointed by the President, to keep tabs on the effort and to advise the President on its progress, and it would require the White House to prepare annual reponts evaluating progress in reducing earthquake risks. Those two provisions would give the effort considerable political visibility. The funds would be shared mostly by the US
Geological Survey, which would be authorised to spend $\$ 75$ million in the next three years, and by the National Science Foundation, whose share would amount to some $\$ 60$ million.

Describing the measure last week, Senator Cranston noted that 39 states are susceptible to major earthquakes. He also pointed out that a major earthquake in a metropolitan area in California would claim thousands of lives and cost billions of dollars in property damage. "We may be courting certain disaster if we fail to take preventive measures now", he said.

The money is, however, far from being safely in the bank for seismic research. To become law, the bill must also be approved by the House of Representatives hefore the end of this year. Key legislators there have said, however, that they will hold hearings on the measure as swiftly as possible. The Ford administration is on record as opposing the measure, chiefly because it insists that earthquake research is already proceeding with sufficient priority. Most important, cven if the bill is passed and signed into law, the money would still have to go through the annual appropriations process before it can be made available. Nevertheless, the electoral appeal of the measure is obvious and the time is probably ripe for the bill to be approved. for example, the Southern California Edison Company cancelled plans to build a massive coal-fired plant in Utah because of environmentalist opposition. Opponents thus argue that without painful conservation measures and greater reliance on imported oil, California would not be able to meet its energy needs, and it will suffer economically as a result.

One factor clouding the picture in the late stages of the campaign concerns the effect that passage of the three nuclear energy bills by the state legislature will have on the prospects for Proposition 15. The bills, which deal with nuclear safety, safeguards and waste storage (but not with liability limits) would require the recently created California Energy Resources, Conservation and Development Commission to determine whether the federal government has dealt satisfactorily with nuclear power problems, and the commission's findings would have to be approved by a simple majority of the legislature. Unless such approval is given, no new reactors could be built, but the legislation would leave untouched the three existing plants and the four under construction.

Another uncertain factor is whether or not Proposition 15 would survive a court challenge. If the proposition is passed, the nuclear industry would be certain to challenge its constitionality, arguing that it would usurp the federal government's power to set regulations for nuclear power. Legal experts are divided on the likely outcome of such a challenge, but two Stanford University law professors who have studied the matter conclude that most of Proposition 15's provisions would just survive a court test.

If, as now seems likely, Proposition 15 will be defeated by a small margin, it is likely that both sides would claim a victory. In a speech delivered on May 4 at the Forum Atomique Européen in Madrid, Carl Walske, president of the Atomic Industrial Forum, predicted victory for the opponents of Proposition 15, and claimed that such a result would sound the death knell of the anti-nuclear movement. The campaign, he said, "may well be their last big drive".

But if supporters of Proposition 15 come even close to victory, they will claim success, arguing that they were defeated by the industry's money and that the extent of the nuclear opposition is such that there is no mandate for a vast expansion of nuclear power in California. As a spokesman for the Yes on 15 Committee put it last week, the industry knows that it must defeat the proposition heavily, because anything short of a landslide defeat would be called a victory by the antinuclear groups. 